\title{
Corporate Entrepreneurship: a Strategic and Structural Perspective
}

\author{
Dr. Joao Ferreira
}

\begin{abstract}
Recently there has been a growing interest in the use of corporate entrepreneurship as a means for corporations to enhance the innovative abilities of their employees and, at the same time, increase corporate success through the creation of new corporate ventures. However, the creation of corporate activity is difficult since it involves radically changing internal organisational behaviour patterns. Researchers have attempted to understand the factors that stimulate or impede corporate entrepreneurship. They examined the effect of a firm's strategy, organisation and external environment. It appears that the environment plays a profound role is influencing corporate entrepreneurship whereas there is consensus that the external environment is an important antecedent of corporate entrepreneurship.

Focus on the environment, the literature highlights two research questions that deserve examination. First, how do firms that compete in different environments vary in the corporate entrepreneurship activities? Second, which corporate entrepreneurship activities are conductive to superior performance in different environments? This paper develops the theoretical foundation of theses questions and focuses on the relationship between corporate entrepreneurship and strategic management in a integrating model of corporate entrepreneurship, giving special attention to the strategic behaviour, corporate context and organisational types.
\end{abstract}




\section{INTRODUCTION}

Corporate entrepreneurship is an evolving area of research. Today, there is no universally acceptable definition of corporate entrepreneurship (Gautam \& Verma, 1997). Authors use many terms to refer to different aspects of corporate entrepreneurship: intrapreneurship (Kuratko et al., 1990), internal corporate entrepreneurship (Schollhammer, 1982), corporate ventures (Ellis and Taylor, 1987; MacMillan et al., 1986), venture management (Veciana, 1996), new ventures (Roberts, 1980) and, internal corporate venturing (Burgelman, 1984).

For despite the growing interest in corporate entrepreneurship, there appears to be nothing near a consensus on what it is. Some scholars emphasising its analogue to new business creation by individual entrepreneurs, view corporate entrepreneurship as a concept that is limited to new venture creation within existing organisations (Burgelman, 1984). Others argue that the concept of corporate entrepreneurship should encompass the struggle of large firms to renew themselves by carrying out new combinations of resources that alter the relationships between them and their environments (Baumol, 1986; Burgelman, 1983). According to Zahra (1991) corporate entrepreneurship refers to the process of creating new business within established firms to improve organisational profitability and enhance a firm's competitive position or the strategic renewal of existing business.

Burgelman (1984: 154) conceptualises the definition of corporate entrepreneurship as a process of "extending the firm's domain of competence and corresponding opportunity set through internally generated new resource combinations". The term "new resource combinations" is interpreted to be synonymous with innovation in the Schumpeterian sense. Thus corporate entrepreneurship is conceived of as the effort to extend an organisation's competitive advantage through internally generated innovations that significally alter the balance of competition within an industry or create entirely new industries. Corporate entrepreneurship is a process of organisational renewal (Sathe, 1989) that has two distinct but related dimensions: innovation and venturing, and strategic stress creating new business through market developments on by undertaking product, process, technological and administrative innovations. The second dimension of corporate entrepreneurship embodies renewal activities that enhance a firm's ability to compete and take risks (Miller, 1983). Renewal has many facets, including the redefinition of the business concept, reorganisation, and the introduction of system-wide changes for innovation.

According to Kuratko et al. (1990) the need to pursue corporate entrepreneurship has arisen from a variety of pressing problems including: (1) required changes, innovations, and improvements 
in the marketplace to avoid stagnation and decline (Miller and Friesen, 1982); (2) perceived weakness in the traditional methods of corporate management; and (3) the turnover of innovative-minded employees who are disenchanted with bureaucratic organisations.However, the pursuit of corporate entrepreneurship as a strategy to counter these problems creates a newer and potentially more complex set of challenges on both a practical and theoretical level.

The identification of the various dimensions or factors of corporate entrepreneurship, of course, is a broad arena to consider and the principal objective of this paper is to extend the theory of entrepreneurship by providing a conceptual model on corporate entrepreneurship in organisations and on strategic process.

\section{DOMAIN OF CORPORATE ENTREPRENEURSHIP}

Corporate entrepreneurship activities can be internally or externally oriented (MacMillan et al., 1986; Veciana, 1996). Internal activities are typified as the development within a large organisation of internal markets and relatively small and independent units designed to create internal testmarkets or expand improved or innovative staff services, technologies, or production methods within the organisation. These activities may cover product, process, and administrative innovations at various levels of the firm ${ }^{1}$ (Zahra, 1991). Schollhammer (1982) has proposed that internal entrepreneurship expresses itself in a variety of modes on strategies - administrative (management of research and development), opportunistic (search and exploitation), imitative (internalisation of an external development, technical or organisational), acquisitive (acquisitions and mergers, divestments) and incubative ${ }^{2}$ (formation of semi-autonomous units within existing organisations).

External entrepreneurship can be defined as the first phenomenon that consists of the process of combining resources dispersed in the environment by individual entrepreneurs with his or her own unique resources to create a new resource combination independent of all others (Gautam \& Verma, 1997). External efforts entail mergers, joint ventures, corporate venture, venture nurturing, venture spin-off and others ${ }^{3}$.

\footnotetext{
${ }^{1}$ For more details to see Veciana (1996)

${ }^{2}$ The incubator units "are designed to infuse innovative developments into the corporation, to explore and pursue novel business opportunities, and to develop them into viable, profitable entities" (Schollhammer, 1982:216)

${ }^{3}$ For more details to see Roberts (1980) and Veciana (1996)
} 
Whether internal or external in focus, corporate entrepreneurship can be formal or informal. Informal efforts occur autonomously, with or without the blessing of the official organisation. Such informal activities can result from individual creativity or pursuit of self-interest, and some of these efforts eventually receive the firm's formal recognition and thus become an integral part of the business concept. According to Zahra (1991:262) a comprehensive of corporate entrepreneurship must incorporate both formal and informal aspects of corporate venturing, as follows: "corporate entrepreneurship refers to formal and informal activities aimed at creating new business in established companies through product and process innovations and market developments". These activities may take place at the corporate, division (business), functional, or project levels, with the unifying objective of improving a firm's competitive position and financial performance (Morris et al., 1988).

In light of these manifestations, it is evident that corporate entrepreneurship is not confined to a particular business size or a particular stage in an organisation's life cycle, such as the start-up phase. In a competitive environment, entrepreneurship is an essential element in the long-range success of every business organisation, small or large, new or long established.

\section{CORPORATE ENTREPRENEURSHIP AND STRATEGIC MANAGEMENT}

The strategy literature identifies three types of corporate entrepreneurship. One is the creation of new business within an existing organisation - corporate venturing or intrapreneurship as it is called (for example, Burgelman, 1983; Kuratko et al., 1990; Guth \& Ginsberg, 1990). Another is the more pervasive activity associated with the transformation or renewal of existing organisations (Stopford $\&$ Fuller, 1994). The third is where the enterprise changes the rules of competition for its industry in the manner suggested by Schumpeter and implied by Stevensen and Gumpert (1985).

Changes in the pattern of resource deployment - new combinations of resources in Schumpeter's terms - transform the firm into something significantly different from what it was before - something 'new'. This transformation of the firm from the old to the new reflects entrepreneurial behaviour. Corporate venturing, or new business development within an existing firm, is only one of the possible ways to achieve strategic renewal. Strategic renewal involves the creation of new wealth through new combinations of resources. This includes actions such as refocusing a business competitively, making major changes in marketing or distribution, redirecting product development, and reshaping operations (Guth and Ginsberg, 1990). 
According to Burgelman (1983) relatively little is know about the process through which large, complex firms engage in corporate entrepreneurship. To Burgelman the corporate entrepreneurship refers to the process whereby firms engage in diversification through internal development. Such diversification requires new resources combinations to extend the firm's activities in areas unrelated, or marginally related, to its current domain of competence and corresponding opportunity set. In the Schumpeterian sense, diversification through internal development is the corporate analogue to the process of individual entrepreneurship (Russell, 1995). Corporate entrepreneurship, typically, is the result of the interlocking entrepreneurial activities of multiple participants.

The role of entrepreneurial activity is to provide the required diversity. Whereas order in strategy can be achieved through planning and structuring, diversity in strategy depends on experimentation and selection. The task of strategic management is to maintain an appropriate balance between these fundamentally different processes. These insights have implications for design of organisational arrangements and for the development of strategic managerial skills. Miller and Friesen (1982) created a distinction between the concepts of corporate entrepreneurship and an entrepreneurial strategy. An entrepreneurial strategy is define as the frequent and persistent effort to establish competitive advantage through innovation, while corporate entrepreneurship can describe any attempt, even if infrequent, to implement innovation. Corporate entrepreneurship is to a great extent a social process in which innovations are socially constructed through a series of trial-and-error learning episodes (Van de Ven, 1986). Theses episodes constitute a complex network of interpersonal transactions involving an increasing number of people and volume of information as the process unfolds over time.

\section{Strategic Behaviour and Corporate Entrepreneurship}

Burgelman (1983) asserted that corporate entrepreneurship represents an important source of strategic behaviour. Autonomous corporate entrepreneurship ventures are initiated by the owner or the other members of the organisation other than the small business manager. The autonomous strategic behaviour of middle managers provides the raw material - the requisite diversity - for strategic renewal. Top management actions and responses in relation to the autonomous strategic behaviour of middle managers may significantly influence the frequency and success of entrepreneurial effort in the firm. Burgelman (1983) has proposed an inductively derived model of the dynamic interactions between different categories of strategic behaviour, corporate context 
processes, and a firm's concept strategy. This model $^{4}$, represented in Figure 1, can be used to elucidate the nature and the role of corporate entrepreneurship.

\section{Figure 1 - A Model of Interaction of Strategic Behaviour, Corporate Context and Concept of Strategy}

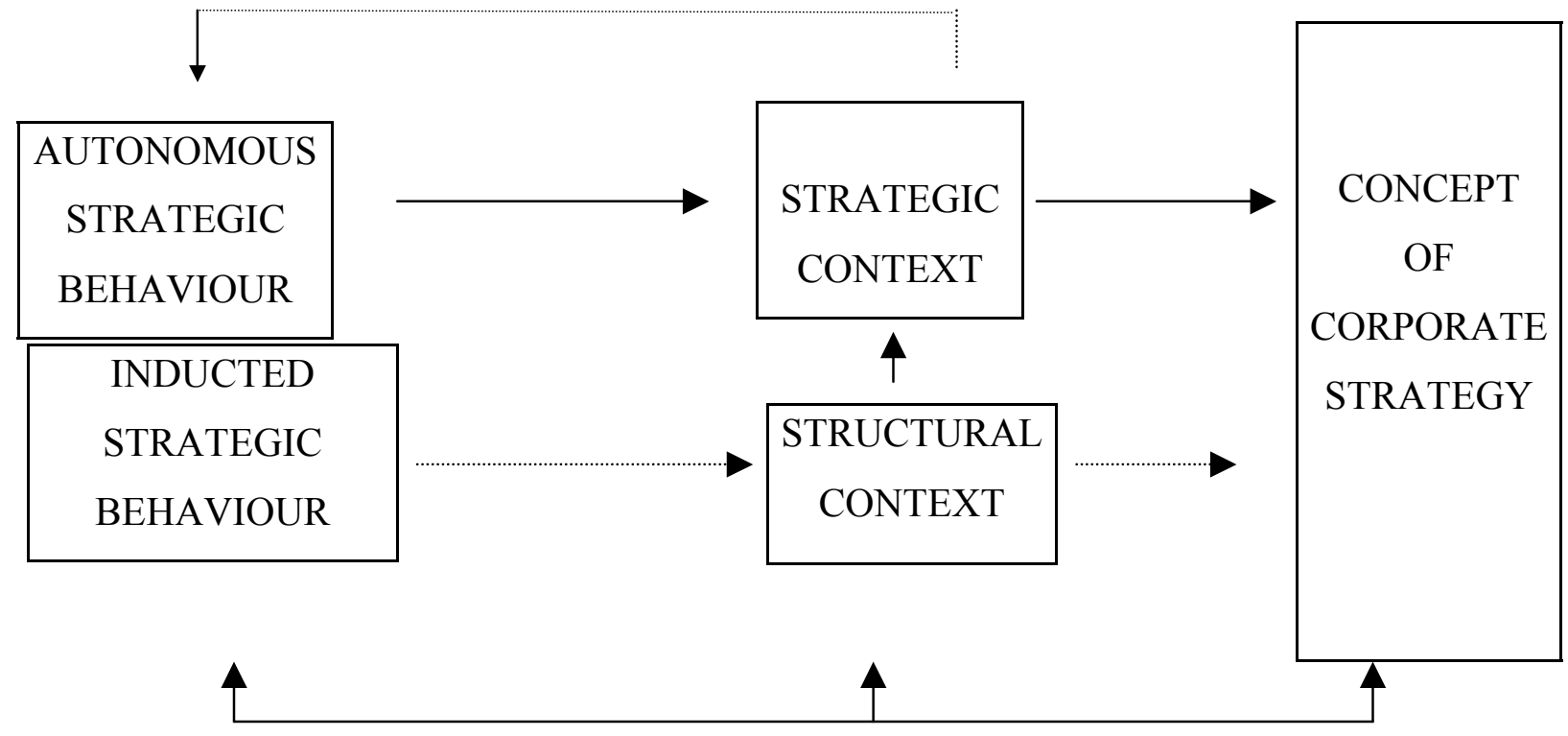

Strong Influence

Weak Influence

Source: Burgelman (1983: 1351)

In this model, the current concept of strategy represents the more or less explicit articulation of the firm's theory about the basis for its past and current successes and failures. It provides a more or less shared frame of reference for the strategic actors in the organisation, and provides the basis for corporate objective-setting in terms of its business portfolio and resource allocation. The model proposes that two generic categories of strategic behaviour can be discerned in such large, complex firms: Inducted and Autonomous.

Inducted strategic behaviour uses the categories provided by the current concepts of strategic to identify opportunities in the "enactable environment". Being consistent with the existing categories used in the strategic planning system of the firm, such strategic behaviour generates little equivocally in the corporate context. Autonomous Strategic Behaviour introduces new categories for

\footnotetext{
${ }^{4}$ This model inductively derived, is isomorphous to the variation-selection-retention model currently emerging as a major conceptual framework for explaining organisational survival, growth, and development in organisations and environment in Aldrich, 1979 (Burgelman, 1983)
} 
the definition of opportunities. Entrepreneurial participants, at the product/market level, conceive new business opportunities, engage in project championing efforts to mobilise corporate resources for these new opportunities, and perform strategic forcing efforts to mobilise corporate resources for theses new opportunities, and perform strategic forcing efforts to create momentum for their further development. Structural Context refers to the various administrative mechanisms which top management can manipulate to influence the perceived interests of the strategic actors at the operational and middle levels in the organisation. It intervenes in the relationship between induced strategic behaviour and the concept of strategy, and operates as a selection mechanism - a diversity reduction mechanism, on the stream of induced strategic behaviour. Corporate entrepreneurship is unlikely to take place through the induced strategic behaviour loop ${ }^{5}$. Incremental innovation can occur, but no radically new combinations of productive resources are likely to be genered in this loop. The firms also are likely to generate a certain amount of autonomous strategic behaviour. From the perspective of the firm, autonomous strategic behaviour provides the raw material - the requisite diversity - for strategic renewal. As such, autonomous strategic behaviour is conceptually equivalent to entrepreneurial activity - generating new combinations of productive resources - in the firm. In this model, Burgelman (1983) identified corporate entrepreneurship with the autonomous strategic behaviour loop. Autonomous strategic behaviour takes shape outside of the current structural context. yet, to be successful, it needs eventually to be accepted by the organisation and to be integrated into its concept of strategy.

Strategic context refers to the political mechanisms through which middle managers question the current concept of strategy, and provide top management with the opportunity to rationalise, retroactively, successful autonomous strategic behaviour.

\section{Corporate Entrepreneurship and Organisational Types}

\footnotetext{
${ }^{5}$ The identification of the autonomous strategic behaviour loop is the result of grounded theorising efforts based on a field study of the internal corporate venturing process in the large, diversified firm (Burgelman, 1983:1352).
} 
The integration of corporate entrepreneurship and strategic management can be related to typologies of organisations and of strategic process proposed by Miles and Snow (1978) and Mintzberg (1973), respectively (Burgelman, 1983; Veciana, 1996).

Miles and Snow have suggested four empirically-derived types of organisations: (1) "Defenders" have narrow product-market domains; (2) "Prospectors" search almost continually for new opportunities and experiment regularly with potential responses to emerging environmental trends. Their emphasis on innovation; (3) "Analyzers" typically operate in two types of product-market domains: one rapidly changing, the other relatively stable. Their top management must be capable of dealing with strategy in different modes; and (4) "Reactors" that are unable to answer with effectiveness to environment alterations. They make changes just when are obligated. Mintzberg (1973) has proposed a typology of strategic processes which would seem to parallel Miles and Snow's organisational typology. Defenders can be characterised by a planning mode, prospectors are likely to use an entrepreneurial mode, and Reactors are likely to be characterised by an adapting mode. This typology has no analogue for Analyzer type, but, being a hybrid, it can be viewed in Mintzberg's terms as a mixture of the dealing with strategy in different modes.

Miller and Friesen (1982) identified two strategic postures which they called conservative and entrepreneurial. Each posture was associated with a specific configuration of organisational variables. Strategy in the entrepreneurial configuration is characterised by a tendency to seek product-market innovation as a source of competitive advantage, a proactive posture in seeking change and a moderate propensity to take risks. The conservative posture, in contrast pursues innovation only reluctantly, tending to emphasise existing performance routines.

Those typologies, as well as the simple dichotomy between "entrepreneurial" and "conservative" firms proposed by Miller and Friesen (1982), Burgelman (1983) derived the follows model (Figure 2): 
Figure 2 - A Reinterpretation of the Miles \& Snow and Mintzberg Typologies

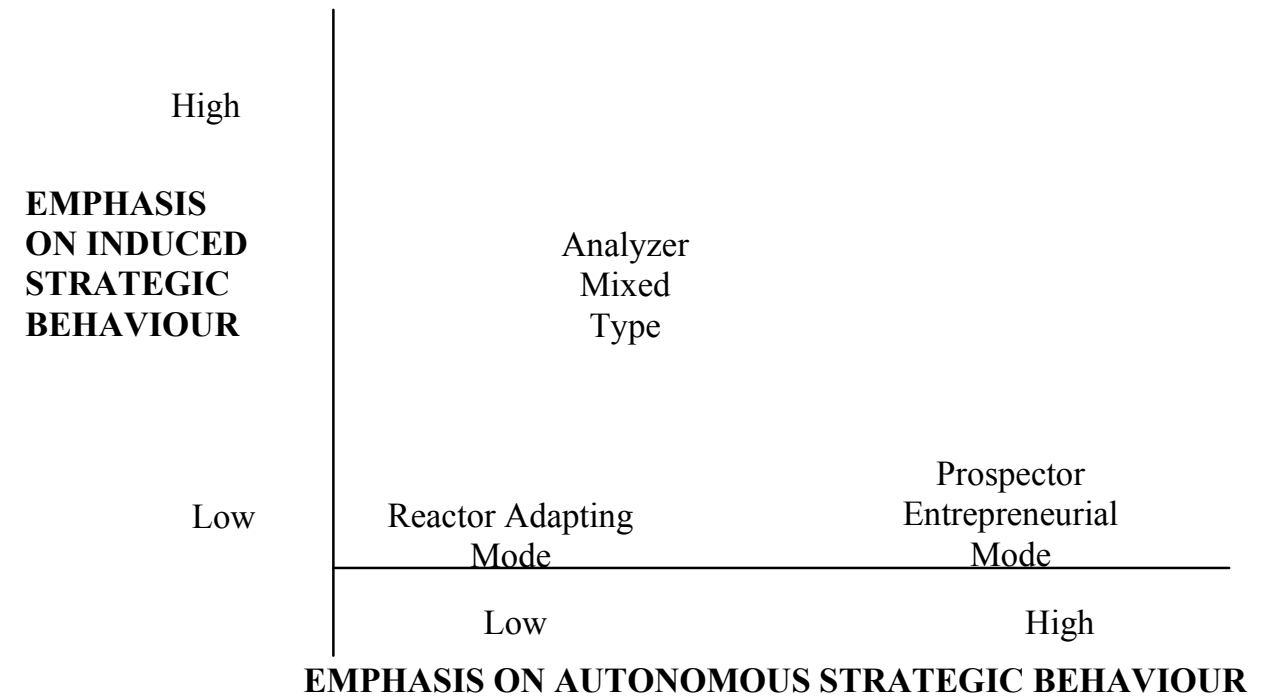

Source: Burgelman (1983:1358)

Different firms are characterised by different combinations of autonomous and induced strategic behaviour, and the typologies are only special cases of this. The model could be used to raise questions about the long-term viability of each of these types. Also, it is interesting to not that, conceptually, the strategic management problem of finding the optimal level of corporate entrepreneurship could possibly be formulated in terms of a constrained optimisation model.

\section{IV - A FRAMEWORK FOR MAPPING CORPORATE ENTREPRENEURSHIP}

Several studies have appeared to advance the development of a theory of corporate entrepreneurship. Zahra (1991) developed a model of corporate entrepreneurship based on environmental, strategic and organisational variables and empirically tested the model. Russell and Russell (1992) have also developed and tested a model of intrapreneurship based on environmental, structural, strategic, and cultural variables. Hornsby et al. (1993) have proved an interactive model of the decision to act intrapreneurially, which is focused on individual and organisational variables. Covin and Slevin (1991) analysed strategic and structural variables and tested the relationship between intrapreneuring and firm performance. Their model surveys much of the literature on corporate entrepreneurship and includes the following variables: entrepreneurial posture, external (environmental and industry measures), internal (structural and cultural measures), and strategic (mission strategy and competitive tactics). 
A complete model of corporate entrepreneurship must provide an explanation of how a flow of creative ideas are produced and how innovation-supporting behaviours become part of the development process in entrepreneurial organisations (Russell, 1995). Building on earlier models of strategic management, Guth and Ginsberg (1990) present one model that portrays the theoretical connections that can be drawn from corporate entrepreneurship to the other conceptual elements of the field of strategic management. In their model, Guth \& Ginsberg (1990) identified five classes into corporate entrepreneurship: (1) environment influences corporate entrepreneurship; (2) Strategic leaders influence corporate entrepreneurship; (3) organisation form/conduct influences corporate entrepreneurship; (4) organisational performance influences corporate entrepreneurship, and (5) Corporate entrepreneurship influences performance.

(1) Environment Influences Corporate Entrepreneurship: In this category, Guth and Ginsberg (1990) included: (a) The impact of major environmental shifts, such as deregulation, can influence changes in strategy in a non-random way, with organisations (in the aggregate) moving away from one generic strategy towards other generic strategies; (b) The more dynamic and hostile the environment, the more firms will be entrepreneurial; (c) Industry structure affects opportunities for successful new product development. Clearly, changes in industry competitive structures and the technologies underlying them affect corporate entrepreneurship. Opportunities for new products and services stem from development of new technology and/or commercialisation of technologies developed by others. Both opportunities and problems stem from the potential of the firm and its competitors in an industry to find new combinations of resources that lead to competitive advantage.

(2) Strategic leaders Influence Corporate Entrepreneurship: Guth and Ginsberg (1990) included, here, the following factors: (a) The management style of top managers affects the level and performance of new corporate ventures; (b) Middle managers effectiveness at building coalitions among peers and higher-level managers in support of their entrepreneurial ideas affects the degree of success in their implementation; (c) Banks that are more innovative are managed by more highly educated teams, who are diverse with respect to their functional areas of expertise. Many would argue that entrepreneurial behaviour in organisations is critically dependent on the characteristics, values/beliefs, and visions of their strategic leaders. The role of both individual managers and management teams in corporate entrepreneurship warrants considerable further research. Since innovation is an uncertain, incremental process, strategic managers cannot apply traditional planning techniques to attempt to control entrepreneurial venturing (Quinn, 1985). 
(3) Organisation Conduct/Form Influences Corporate Entrepreneurship: Guth and Ginsberg (1990)

refer two factors: (a) Firms pursuing strategies of acquisitive growth have lower levels of R\&D intensity than firms pursuing strategies of internal growth through innovation; (b) Creating new business venture units in larger organisations does not affect the level of sales from new products. Several researchers have noted a relationship between an organisation's formal strategy and innovation. Covin and Slevin (1991:13) state that mission strategies based upon building market share are more likely to incorporate entrepreneurial ventures based on innovation. They also note that the "entrepreneurial posture" of a firm represents a "strategic philosophy concerning how the firm should operate".

(4) Organisational Performance Influences Corporate Entrepreneurship: In this category, Guth and Ginsberg (1990) included: (a) Successful firms make more radical and more frequent product and process innovations than unsuccessful firms; (b) Organisations which experience performance downturns tend to innovate new practices and change strategic directions only after prolonged decline leads to changes in top management. Innovation and radical change may be precipitated when firms have excess resources that allow them to seize upon opportunities that arise; they also may be induced by crises or severe external threats. More research is needed to shed light on questions concerning the conditions that moderate the influence of organisational performance on innovation and strategic renewal.

(5) Corporate Entrepreneurship Influences Performance: Guth and Ginsberg (1990) refer, in this category three factors: (a) Scale of entry in new product introductions affects performance; (b) Independent, venture-backed start-ups, on average, reach profitability twice as fast and end up twice as profitable as corporate start-ups; (c) Early entry in new-product markets does not affect performance. It is clear that new ventures often take several years to turn into contributors to overall corporate profit performance. Organisational re-creations may often have short-run negative performance consequences.

\section{1 - A Integrating Conceptual model of Corporate Entrepreneurship}

The foregoing discussion has exposed a number of gaps in the existing knowledge about corporate entrepreneurship (Gautma \& Verma, 1997). On the conceptual front, they find that there is a lack of integrative models. Moreover, there is not much clarity on the most few empirically - supported studies, but most of them concentrate on the individual characteristics of entrepreneurs. Not many have attempted to study macro-organisational behaviour. An analysis of the interplay between 
individual, organisational and environmental factors is crucial for understanding the entrepreneurial process. Studies on entrepreneurial behaviour at the firm level will certainly be useful to better define the process and domain of corporate entrepreneurship.

The firm level analyses of entrepreneurship are important and the impact from the environment needs to be considered, in addition to more traditional studies, preoccupied with the entrepreneur. When conducting firm-level analyses of entrepreneurship, strategic issues play an important role. In this investigation, environmental-level, firm-level and individual-level analyses will be combined as depicted in Figure 4. Three theoretical constructs are suggested, which may influence the degree or intensity of a firm's strategic-orientation. Each of these constructs, or sets of variables, have multiple components that vary in their potential positive or negative influence on strategic orientation. The firm's degree of strategic orientation, in turn, influences its growth and performance levels. Variables from different levels of analysis are integrated in the model: variables relating to the entrepreneur, the firm and the environment (Figure 3). 
Figure 3 - A Integrating Conceptual Model of Corporate Entrepreneurship
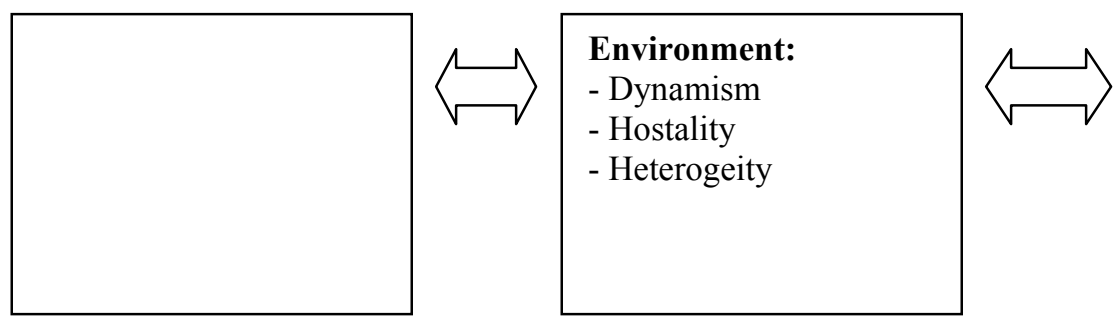

Entrepreneur:

- Resources/Capabilities

-Values/Beliefs

-Charactheristics

-Networks
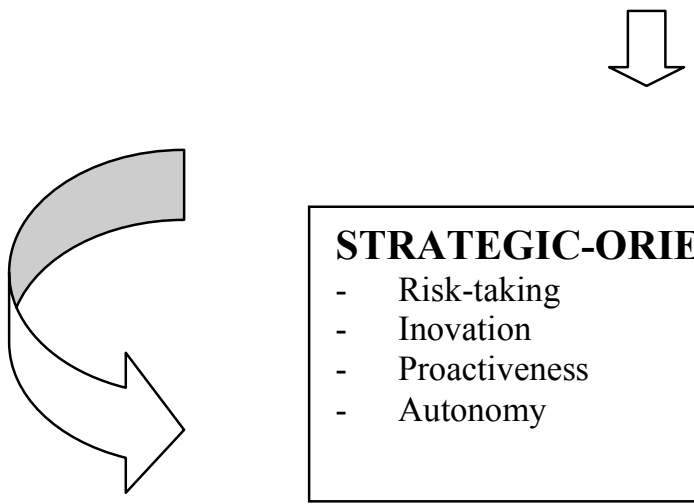

\section{- $\quad$ Risk-taking \\ - Inovation \\ - Proactiveness \\ - Autonomy}

STRATEGIC-ORIENTATION:
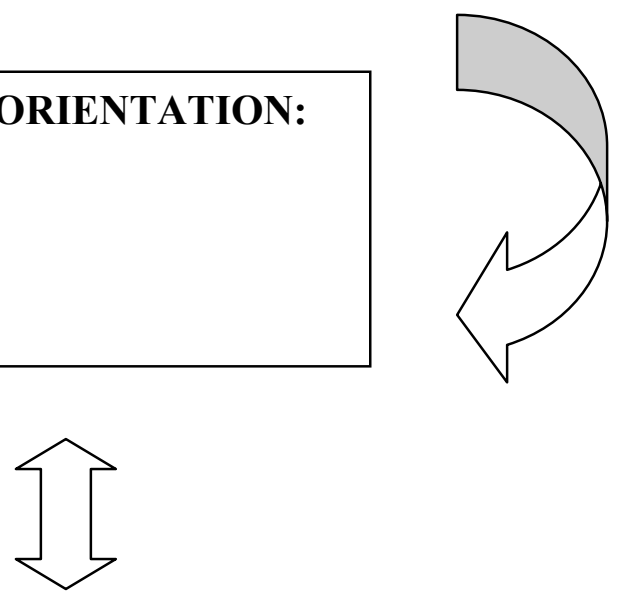

PERFORMANCE \& GROWTH

If firms are new and/or very small, single individuals are responsible for important decisions and actions and there is little need to study entrepreneurial strategy: all revolves around the entrepreneur. Its goals are his goals, its strategy his vision of its place in the world. As the firm becomes larger, but varying across industries, more people inside the firm are likely to get involved in its management. After a firm gets established and starts growing, the smaller the influence from a single individual get and the more professional management becomes. It is important to recognise strategic issues in these firms. Hence, it is important for entrepreneurship researchers to recognise entrepreneurial dimensions of strategy in addition to individual level entrepreneurship. 
In this context, firm level analyses of entrepreneurship are important and the impact from the environment needs to be considered, in addition to more traditional studies, preoccupied with the entrepreneur. When conducting firm-level analyses of entrepreneurship, strategic issues play an important role.

Miller and Friesen (1978) describe the adaptive behaviour of a firm using a biological metaphor. Just as organisms respond to the stimuli they receive, firms adapt through their strategy making to the stimuli they get from the environment. If organisms are able to adapt well to stimuli they will be healthy; if firms are able to select an appropriate strategy, they will be successful. This implies that in a particular environment some strategies will outperform others, i.e. some strategies are better suited to a specific environment than others. Changes in the conditions of the environment create both new opportunities and threats to firms. These changes may alter the congruence between the firm's strategy and environment and pressure on the firm to select a different strategic orientation. However, organisational responses to environment can vary, including not responding at all. Threats and opportunities in the environment can lead to responses with either an internal or external target. These responses could involve mergers as well as actions taken to influence politicians to change decisions.

Some suggestions have been made concerning suitable strategic choices under different environmental conditions (Dess \& Beard, 1984; Miller, 1987; Russel, 1995; Zahra, 1991).These conditions could be viewed as types of precipitating events such as: Dynamism; Hostility; and Heterogeneity. Dynamism refers to the perceived insatiability of a firm's market because of continuing changes. Opportunities emerge from the dynamism of an industry where social, political, technological, and economic changes bring about new developments that can enrich a firm's niche. Corporate entrepreneurship helps to respond to these new competitive forces, either through innovations or imitating competitors' practices. As result firms that view their environment as dynamic will emphasise corporate entrepreneurship.

A hostile environment creates threats to a firm's mission, through increasing rivalry in the industry or depressing demand for a firm's products (or services), thereby threatening the very survival of the firm. Environmental hostility is also expected to stimulate to pursuit of corporate entrepreneurship. Faced with unfavourable environmental conditions, a firm may opt to differentiate its products through intensive marketing and advertising activities in order to sustain customer loyalty or increase penetration of existing segments. And, if hostility continues to intensify in the firm's 
principal markets, these firms consider novel business ideas to replace or supplement their additional business core through internal developments, internal joint venturing, or diversification.

Opportunities also emerge from the heterogeneity of the environment, where developments in one market create new pockets of demand for a firm's products in related areas. Heterogeneity indicates the existence of multiple segments, with varied characteristics and needs, that are being served by the firm (Zahra, 1991). This dimension refers to the number of different organisationally relevant attributes or components of the environment. For instance, two firms may compete in the same industry and serve the same customer groups but will perceive the environment quite differently. One firm may perceive the environment as manageable (simple); the other views it as complex and uncontrollable. These perceptual differences arise from the experience of firms with the external environment. According to Zahra (1991) increased environmental heterogeneity is predicted to be associated with greater use of corporate entrepreneurship. The discussions on environment and its relation to strategy and performance developed under the strategic orientation perspective could be a major contribution to research on small firm performance and growth, as well as in entrepreneurship research in general. According to this perspective, the firm and its environment are not two separate entities independent of each other. Instead, by selecting an appropriate strategy suitable to the firm's environment, the firms can perform well and grow. Research in the area also needs to recognise the fact that different strategic responses to environment threats and opportunities are possible; and that particular strategies are not inherently better. Rather, the success of any particular strategy is dependent on the environment of the firm.

\section{V - CONCLUSIONS}

The relationship between firm's external environment and corporate entrepreneurship activities has been the subject of interest in the literature (Zahra, 1993; Miller, 1987; Russel \& Russel, 1992; Slevin \& Covin, 1989; Veciana, 1996). Whereas there is consensus that external environment is a important antecedent of corporate entrepreneurship (Guth \& Ginsberg, 1990; Gautam \& Verma, 1997), there has been little empirical research on the patterns of the specific associations between these two variables. Also, previous studies have focused on only a few environmental dimensions as the predictors of corporate entrepreneurship, offering only a fragmented view of their potential associations.

Future studies may explore the potential causal chain among these variables (Keats \& Hitt,

1988), testing whether the impact of environment, strategy, and structure on corporate 
entrepreneurship is sequential rather than simultaneous. Further, the effect of motivational and organisational factors on the level of entrepreneurship over time needs to be fully explored. As observed by Schollhammer (1982) there is a need for longitudinal studies to analyse the effectiveness of various internal entrepreneurial strategies. The changes in internal entrepreneurship relative to operating conditions, and the impact of specific external environmental developments and the internal organisational context on various entrepreneurship strategies, have to be looked at carefully.

The volume and diversity of research on the topic of corporate entrepreneurship is already impressive. At the same time, many important issues are largely unexplored. This paper concludes with four questions/implications for future researches, as follows:

(1) conceptual and field work is necessary in order to articulate the domain of corporate entrepreneurship. As recent comprehensive reviews suggest, definitional problems continue to plague this "young" area of research (Zahra \& Covin, 1995). Of particular interest is whether corporate entrepreneurship is a multidimensional or unitary concept (Slevin \& Covin, 1989; Miller \& Camp, 1985), little effort has been mode to identify each of these dimensions and show how they relate to one another. For instance, there are no widely-accepted definition for terms like intrapreneurship, entrepreneurship and corporate entrepreneurship. The literature on entrepreneurship lacks uniform definition and a central core.

(2) There is a need to develop a comprehensive framework for studying the predictors and outcomes of corporate entrepreneurship. There is a need to explore how the relevant environmental dimensions of the proposed model influence corporate entrepreneurship.

(3) Does the "optimum" entrepreneurial configuration vary with the nature of firm's external environment; size of an firm, and the firm's evolutionary phase? In the life-cycle perspective, the firm grows in distinct evolutionary phases, each phase followed by a revolutionary transformation into the next phase (Gray \& Ariss, 1985; Kazanjian, 1988; Greiner, 1972; Quinn $\&$ Cameron, 1983). This gives the growth curve of the firm a stepwise appearance with periods of growth interrupted by volatile crises phases, where the firm is transformed into the next growth phase. The logic behind this discontinuous growth pattern is that in each growth phase, the firm needs to adopt a specific configuration. Usually, the configuration refers to relationships between size, age, strategy, organisation structure and environment. As the firm grows within a particular growth stage, the configuration becomes inappropriate and the firm again needs to transform (Galbraith, 1982; Kimberly, 1979). The life-cycle models are mainly concerned with 
the need for change that growth imposes on the firm, and how this growth affects other characteristics of the firm such as its organisation structure and strategy. Growth creates organisational problems within the firm that need to be resolved (Fombrun \& Wally, 1989; Glueck, 1980; Lavoie \& Culbert, 1978;).

(4) Are some management and leadership styles more effective in creating an entrepreneurial context? The "entrepreneur" plays a main role in the entrepreneurship process. An entrepreneur is most often regarded as an innovative and creative person suitable to manage a firm that emphasises innovation. The proactiveness of a firm indicates that it searches for new opportunities, probably reflecting these characteristics of the entrepreneur. Strategic leaders can also enhance the organisational context for entrepreneurship by reinforcing an innovationsupporting culture and providing the organic structures (characterised by decentralised authority and informal relations between participants) that facilitate innovation development. These and other research questions need to be answered before a practical model of corporate entrepreneurship can be offered.

In sum, corporate entrepreneurship would seem to depend both on the capabilities of operational level participants to exploit entrepreneurial opportunities and on the perception of corporate management that there is a need for entrepreneurship at the particular moment in its development. From the perspective of top management, corporate entrepreneurship is not likely to be a regular concern, non an end in itself. Rather is it a kind of "insurance" against external disturbances or a "safety valve" for internal tensions resulting from pressures to create opportunities for growth.

\section{VI - BIBLIOGRAPHY}

BAUMOL, W. J. (1986): "Entrepreneurship and a Century of Growth", Journal of Business Venturing, 1(2), 141-145;

BURGELMAN, Robert A. (1983): "A Model of the Interaction of Strategic Behavior, Corporate Context, and the Concept of Strategy", Academy of Management Review, 8, 1, 61-71.

BURGELMAN, Robert A. (1983): "A Process Model of Internal Corporate Venturing in the Diversified Major Firm”, Administrative Science Quarterly, 28, 223-244;

BURGELMAN, Robert A. (1984): "Designs for Corporate Entrepreneurship”, California Management Review, 26, 154-166;

COVIN, Jeffrey G. and SLEVIN, Dennis P. (1989): "Strategic management of small firms in hostile and benign environments". Strategic Management Journal, 10 (January), 75-87.

COVIN, Jeffrey G. and SLEVIN, Dennis P. (1991): "A conceptual model of entrepreneurship as firm behaviour". Entrepreneurship Theory and Practice (Fall), 7-25. 
COVIN, Jeffrey G. and SLEVIN, Dennis P. (1991): "A Conceptual Model of Entrepreneurship as Firm Behaviour", Entrepreneurship: theory \& Practice, Fall;

DESS, Gregory G. and BEARD, Donald. W. (1984): "Dimensions of Organizational Task Environments". Administrative Science Quarterly, 29, 52-73.

ELLIS, R. J. and Taylor, N. (1987): "Specifying Entrepreneurship", Frontiers of Entrepreneurship Research, Wellesley, MA: Babson College, 527-542;

FOMBRUN, Charles J. and WALLY, Stefan (1989): "Structuring small firms for rapid growth". Journal of Business Venturing, 4, 2, 107-222.

GALBRAITH, Jay (1982): "The Stages of Growth". Journal of Business Strategy, 3, 1, 70-79.

GAUTAM, Vinayshil and VERMA, Vinnie (1997): "Corporate Entrepreneurship: Changing Perspectives", The Journal of Entrepreneurship, 6, 2, 233-247;

GLUECK, William F. (1980): "Business Policy and Strategic Management". Third Edition, MacGraw-Hill.

GRAY Barbara and ARISS, Sunny S. (1985): "Politics and Strategic Change Across Organational Life Cycles". Academy of Management Review, 10, 4, 707-723.

GREINER, Larry E. (1972): "Evolution and Revolution as Organizations Grow"; Harvard Business Review, July/August; 1

GUTH, William and GINSBERG, Ari (1990): "Guest Editors' Introduction: Corporate Entrepreneurship", Strategic Management Journal, 11, 297-308;

HAMBRICK, Donald C. (1989): “Guest Editor's Introduction: Putting Top Managers Back in the Strategic Picture”, Strategic Management Journal, 10, 5-15;

HORNSBY, J. S. et al. (1993): "An Interactive Model of the Corporate Entrepreneurship Process", Entrepreneurship: Theory \& Practice, Spring, 29-37;

KAZANJIAN, Robert K. (1988): "Relation of Dominant Problems to Stages of Growth in Technology-Based New Ventures", Academy of Management Journal, 31, 2, 257-279.

KEATS, B. and HITT, M. A. (1998): “A Causal Model of Linkages Among Environmental Dimensions, Macro Organisational Characteristics and Performance", Academy of Management Journal, 31, 570-598;

KIMBERLY, John R. (1979): "Issues in the Creation of Organizations: Initation, Innovation and Institutionalization", Academy of Management Journal, 22, 39, 437-457;

KURATKO, Donald et al. (1990): "Developing an Intrapreneurial Assessment Instrument for Effective Corporate Entrepreneurial Environment", Strategic Management Journal, Summer Special Issue, 11, 49-58;

LAVOIE, Dina \& CULBERT, Samuel A. (1978): "Stages of Organization and Development". Human Relations, 31, 5, 417-438.

MACMILLAN, Ian C. et al. (1986): "Corporate Venturing: Alternatives, Obstacles Encountered, and Experience Effects", Journal of Business Venturing 1, 2, 177-192;

MILES and SNOW (1978): "Organizational Strategy, Structure and Process, New York: McGrawHill;

MILLER and CAMO (1985): "Exploring Determinants of Success in Corporate Ventures”, Journal of Business Venturing 1, 1 87-105.

MILLER, Danny and FRIESEN, P. H. (1978): "Archetypes of strategy formulation". Management Science, 24, 9, 921-933.

MILLER, Danny (1983): "The Correlates of Entrepreneurship in Three Types of Firms, Management Science, 29, 7, 770-791;

MILLER, Danny (1987): "The structural and environmental correlates of business strategy". Strategic Management Journal, 8, 55-76. 
MILLER, Danny and FRIESEN, Peter H. (1982): "Innovation in Conservative and Entrepreneurial Firms: two Models of Strategic Management”, Strategic Management Journal, 3, 1-25;

MINTZBERG, Henry (1973): "Strategic Making in Three Modes", California Management Review, XVI-2;

MINTZBERG, Henry (1984): "Power and Organization Life Cycles", Academy of Management Review, 9, 2, 207-224.

MORRIS, Michael et al. (1988): "The Role of Entrepreneurship and Marketing in Established Firms", Industrial Marketing Management, 17, 337-346;

QUINN, J. (1985): "Managing Innovation: Controlled Chaos", Harvard Business Review, MayJune, 73-84

QUINN, Robert E. and CAMERON, K. (1983): "Organizational Life Cycles and Shifting Criteria of Effectiveness: Some Preliminary Evidence"; Management Science, 29, January, 33-51.

ROBERTS, Edward B. (1980): "New Ventures for Corporate Growth", Harvard Business

Review,July/Agust 58, 4, 134-142;

RUSSEL, Robert D. (1995): “An Investigation of Some Organisational Correlates of Corporate Entrepreneurship: Toward a Systems Model of Organisational Innovation"; Entrepreneurship, Innovation and Change, 4, 4, 295-314;

RUSSELL, Robert D. and RUSSEL, C. J. (1992): "Examination of the Effects of Organisational Norms, Organisational Structure and Environmental Uncertainty on Entrepreneurial Strategy". Journal of management, XVIII-4.

SATHE, V. (1989): “Fostering Entrepreneurship in the Large, Diversified Firm”, Organizational Dynamics, 18, 2, 20-32;

SCHENDEL, Dan (1990): "Introduction to the Special Issue on Corporate Entrepreneurship", Strategic management Journal, 11, 1-3;

SCHOLLHAMMER, Hans (1982): “Internal Corporate Entrepreneurship", In C. Kent, D. Sexton and K. Vesper (eds.), Encyclopaedia of Entrepreneurship, Prentice Hall, Englewood Clipp, NJ.; SCHUMPETER, Joseph (1934): "The Theory of Economic Development". Cambridge: MA:

Harvard University Press;

SLEVIN, Dennis and COVIN, Jeffrey (1989): "Strategic Management of Small Firms in Hostile and Benign Environments", Strategic Management Journal, 10, 75-87;

STEVENSON, Howard and GUMPERT, D. E. (1985): "The Heart of Entrepreneurship"; Harvard Business Review, 2;

STOPFORD, John and FULLER, Baden (1994): "Creating Corporate Entrepreneurship", Strategic Management Journal, 15;

VAN DE VEM (1986): "Central Problems in the Management of Innovation", Management Science, 32, 590-607;

VECIANA, José (1996): “Generación y Desarrollo de Nuevos Proyectos Innovadores: "Venture management' o 'Corporate Entrepreneurship"', Economia Industrial, 310/IV;

ZAHRA, Shaker (1991): "Predictors and financial outcomes of corporate entrepreneurship: An explorative study". Journal of Business Venturing, 6, 259-285.

ZAHRA, Shaker (1993): "A conceptual model of entrepreneurship as firm behaviour: A critique and extension". Entrepreneurship Theory and Practice, 16 (Summer), 5-21.

ZAHRA, Shaker and COVIN, Jeffrey (1995): "Contextual Influences on the Corporate Entrepreneurship-Performance Relationship: A Longitudinal Analysis, Journal of Business Venturing, 10; 


\begin{abstract}
About the author:
Author: Dr. Joao Ferreira

Country: Portugal

Degree: Master in Strategic Management and teacher of Beira Interior University - Portugal

Company or Institution: Beira Interior University -Department of Management and Economics Email: (ferreira_joao@hotmail.com)
\end{abstract}

